\title{
6 \\ Stable, Democratic and Western: China and French Colonialism in the Pacific
}

Nic Maclellan

\section{Introduction}

In the 21 st century, France remains a colonial power in the Pacific Islands, administering three non-self-governing territories-New Caledonia, French Polynesia and Wallis and Futuna-as well as the uninhabited Clipperton Island. At a time when China is expanding its trade, investment and political relationships with independent nations like Fiji, Samoa and Papua New Guinea, Chinese corporations have had relatively limited engagement with the three Francophone territories. However, this is steadily changing. Chinese companies have expressed interest in resource and aquaculture projects in the French Pacific dependencies. At the same time, Pacific Island leaders in Noumea and Papeete are looking to increase Chinese tourism and expand trade with China.

In response, Western allies are reinforcing their security engagement with Pacific Island nations in an attempt to blunt growing Chinese influence. Alongside Australia's 'Step-Up', New Zealand's 'Pacific Reset' and the US's 'Pacific Pledge', the ANZUS (Australia, New Zealand and US) governments are also seeking to mobilise strategic partners like France in the Pacific Islands region. Australian politicians, media and think tanks have welcomed any signs that allies like France and the United Kingdom 
will play a greater role in the Pacific Islands, presenting these partners as 'stable, democratic and Western' (Maclellan 2012, 2020). In most cases, however, this support comes without analysis of the implications for local populations, especially those seeking political independence from colonial rule.

This tension between the Western security agenda and the development needs of small island developing states is a central contradiction that will only be exacerbated in coming years. Australia's former consul-general to New Caledonia Denise Fisher has argued that new geopolitical complexity creates significant challenges for the French Government:

France is now one of many more players with interests in the South Pacific and must compete with them for the attention of the small island countries, and even for the attention of the local authorities in France's own collectivities ... The entry of numerous new players, particularly China with its strategic and economic weight, lends a geo-strategic edge even to aid cooperation. Some offer new and different models of economic development, not necessarily compatible with that of France's collectivities in the Pacific (Fisher 2015:30).

The French state has its own strategic interests in the region, both military and economic, that seek to assert sovereignty over the vast 7 million square kilometre exclusive economic zone (EEZ) in the South Pacific (Maclellan 2018d). The governments of New Caledonia, Wallis and Futuna and French Polynesia have their own agenda around the oceans, climate change and resource management, but lack control over key legal and administrative powers because of France's ongoing colonial authority.

Even so, governments in Noumea and Papeete are extending their engagement with non-traditional partners like China. Speaking at a seminar on China's Maritime Silk Road in November 2019, the President of French Polynesia Edouard Fritch saw little difference between investors from China and other nations:

It's the common interest shown by private investors from China and successive French Polynesian Governments that has led to China including French Polynesia in its Silk Road initiative ... We are open to Chinese private investors, just as we were to American, French, European, Samoan or New Zealand investors, in key economic sectors that open up our markets, such as tourism or 
aquaculture. I don't see a difference between an American investor and a Chinese investor. If they are honest, they are all worthy of our friendship, whatever their nationality (Fritch 2019:4). ${ }^{1}$

This chapter begins by discussing French President Emmanuel Macron's promotion of an India-Australia-France axis to contribute to strategic containment of China in the Indo-Pacific region. It then presents four examples where France's Pacific dependencies are, in contrast, looking to greater engagement with China. Their means for increasing engagement include increasing trade with China, attempts to increase Chinese tourism, the establishment of a Chinese fishing enterprise on Hao Atoll in French Polynesia, and Chinese involvement in New Caledonia's nickel industry.

Each case study discusses the successes and failures of the engagement and tensions between Chinese corporate and Pacific government agendas, highlighting the lack of nuance and evidence in much media discussion of China in the Pacific.

\section{France and the rise of the Indo-Pacific}

\section{France as a Pacific power}

Philippe Gomès is president of the anti-independence party Calédonie Ensemble and serves as one of New Caledonia's two representatives in the French National Assembly. In an interview, Gomès argued that France's ongoing presence in the South Pacific serves as protection against rising Chinese power:

China is an exceptional financial power, which allows them to invest widely and heavily, wherever they want and notably in the Pacific. With China in the region, we're like flies; they'll swat us just like that. To leave the French Republic is to leave us at the mercy of the Chinese. Frankly, to replace France with the Chinese is not on. This would be the exact opposite of independence. ${ }^{2}$ 
At a time of geopolitical tensions between China and the US, regional interventions are increasingly framed by the concept of the Indo-Pacific rather than Asia-Pacific. In much academic and media debate over France's role, however, Indo-Pacific is conflated with the South Pacific, even though the strategic and economic dynamics of India and East Asia are fundamentally different from those facing small island developing states. As noted by the Prime Minister of Samoa Tuilaepa Sailele Malielegaoi:

The renewed vigour with which a 'Free and Open Indo-Pacific strategy' is being advocated and pursued leaves us with much uncertainty. For the Pacific, there is a real risk of privileging Indo over the Pacific (Malielegaoi 2018:6).

The Indo-Pacific framework was used by French President Emmanuel Macron when he visited Australia and New Caledonia in May 2018:

France is a great Indo-Pacific power, and it has great power in the Indo-Pacific region through its territories New Caledonia, Wallis and Futuna and French Polynesia, as well as Mayotte and Reunion ... [The Indo-Pacific region has] more than 8,000 of our military personnel who project our national defence, our interests, our strategy; the region has more than three quarters of the vast maritime zone- that makes us the second largest maritime power in the world (Macron 2018).

In an interview, France's then ambassador to the South Pacific Christian Lechevry argued that 'the notion of the Indo-Pacific may be new for you [Australians], but not for France, given our long-standing presence in both the Indian and Pacific Oceans'.

A 2018 publication on Indo-Pacific security by the French Defence Ministry highlights France's interests in both the Indian and Pacific Oceans based on its colonial possessions, where 'permanent military basing allows France to fulfil the security responsibilities of a resident power of the Indo-Pacific' (Ministry of Defence 2018). During President Macron's visit, officials argued that ongoing French colonial control in New Caledonia was crucial to France's Indo-Pacific strategy. This was echoed in media coverage:

3 France's then ambassador to the South Pacific Christian Lechevry, 5 September 2018. Pacific Islands Forum, Nauru. Interview with author. 
In terms of geo-politics, losing control over New Caledonia's foreign affairs and defence would undermine Macron's strategy, of which Australia is a stated ally, to strengthen or protect France's influence in the Indo-Pacific region-presumably as a hedge against China (Patrick 2018).

For this reason, France has been extending its diplomacy with Pacific regional networks. In 2016, after extensive French lobbying, the Pacific Islands Forum (PIF) leaders meeting in Pohnpei 'accepted French Polynesia and New Caledonia as full members of the Pacific Islands Forum' (PIF Secretariat 2016:5).

This decision makes them full participants in the regional body, but has raised concern about France's increased influence over PIF policymaking. Former Fiji foreign minister Kaliopate Tavola (2019:26) has noted:

How can FICs [Forum Island countries], for example, persist at the UN [United Nations] to push for decolonisation when the prospects of increased French influence as a development partner are increasingly being programmed into regional activities?

PIF membership for the two dependencies further integrates France into regional security policy, given that Paris retains sovereign control over their defence, military forces, policing and many aspects of foreign policy. It also amplifies the capacity of the French Republic to intervene in regional debates about the Blue Pacific and ocean policy (Maclellan 2018d).

France is already a member of the Quadrilateral Defence Coordination Group alongside the three ANZUS allies. Under the March 2017 Statement of Enhanced Strategic Partnership between Australia and France, the relationship is increasingly global rather than regional, focused on North Korea, the South China Sea and the Middle East. However, as then prime minister Malcolm Turnbull welcomed President Macron to Australia in May 2018, he made it clear that he sees France as a long-term ally in the South Pacific:

France is a Pacific power. It is a Pacific nation and its significant presence in the region can only bring benefits to Australia and to the region more broadly. We welcome that and we'll continue to work closely with France in our region (Turnbull and Macron 2018). 
This partnership is dominated by Australia's purchase of submarine technology from France in an AU\$80 billion deal with France's Naval Group (Carroll and Ell 2017). After a decade of negotiation, the two countries also signed a new Mutual Logistics Support Agreement in 2018 to allow French and Australian naval and air units to use each other's ports, fuel and logistics in the Pacific (Maclellan 2009).

During their 2018 visit, Macron and Turnbull signed a new Vision Statement on the Australia-France Relationship, extending an agreement first signed by former prime minister Kevin Rudd of the Australian Labor Party (ALP) in 2012. In Australia, support for France's colonial presence in the Pacific region is bipartisan, with leading ALP politician Richard Marles stating:

France is a stable and strong democracy which projects the values of democracy within a region where democracy is young and we can't take it for granted ... France is a very positive player within the Pacific, and we very much welcome France's ongoing role in the Pacific (Maclellan 2012; Marles 2012).

\section{Strengthening the quad against China}

During his 2018 visit to Australia, President Macron welcomed China's economic growth and engagement with world markets. However, he stressed that the Chinese Government must operate within the trade and security framework established by the Western allies:

What's important is to preserve a rule-based development in the region and especially in the Indo-Pacific region. It's to preserve the necessary balances in the region (Turnbull and Macron 2018).

In its 2017 Foreign Policy White Paper, Australia highlighted this 'rules-based order' as a central pillar of regional policy (DFAT 2017). To maintain this order, it promotes 'the quad'-a structure to increase quadrilateral coordination between Australia, the US, Japan and India to contain China-even though successive Australian governments have denied that containment is the objective of these strategic partnerships.

The French state is eager to engage with this quad network. During a 2016 visit to Canberra, then defence minister Jean-Yves Le Drian promoted an Australia-France-India axis as the basis of strategic cooperation in the region, saying, 'We need to think of a three-way partnership that includes India if we want security in the Indo-Pacific region' (Nicholson 2016). 
During his 2018 visit to Australia and New Caledonia, President Macron again highlighted France's connection to both India and Australia, two countries where the French Government is actively promoting arms sales:

Our shared priority is to build this strong Indo-Pacific axis to guarantee both our economic and security interests. The trilateral dialogue between Australia, India and France has the possibility to play a central role in this (L'Express 2018).

Some French commentators have suggested that this axis relies on Paris maintaining colonial rule in New Caledonia, 'given the new strategic ambition-Noumea is the bridgehead for France in its axis with New Delhi and Canberra, through which it hopes to block Chinese expansion in the Pacific' (Hacquemand 2018).

During a March 2018 trip to New Delhi, President Macron signed a Joint Strategic Vision of India-France Cooperation in the Indian Ocean Region to reinforce France's strategic partnership with India. France is also looking to extend bilateral security agreements with Japan and other East Asian and Southeast Asian nations on defence policy (Rigaud 2016).

\section{French military (in)capacity in the South Pacific}

In recent years, successive French defence ministers have announced that France would coordinate naval patrols with the United Kingdom in the South China Sea in support of freedom of navigation (Panda 2016). In June 2018, Defence Minister Florence Parly noted that British withdrawal from the European Union after Brexit would not affect their ongoing defence cooperation:

When we meet here in Asia, we may no longer be part of the same European club, but we still share something of very deep significance: vision, strength, values and a willingness to protect them (Brattberg et al. 2018).

This increasing strategic cooperation is targeted at China, but is being used to justify French colonialism in the Pacific Islands (Vandendyck 2018). During his May 2018 visit to Noumea, President Macron reaffirmed the notion of France as a mid-sized global power that would be weakened by the loss of its overseas colonies: 
What I would like to say from the bottom of my heart, and in my role as President of the Republic, is that France would not be the same without New Caledonia ... France would be less beautiful without New Caledonia, because New Caledonia is part of this global France, the France which exists in this region of the world, tens of thousands of kilometres from Paris. At heart, France's very purpose is to shine across all continents and all oceans (Macron 2018).

Despite this, the conflation of Indo-Pacific security with France's colonial presence in the South Pacific is misleading. The notion that the French Pacific collectivities are a bulwark against Chinese expansionism is undercut by the reality that France deploys very few military assets in the South Pacific. After the 2007-08 global financial crisis, there was a significant draw down of French forces based in the region, including a 50 per cent reduction in French Polynesia (Maclellan 2009).

France's regional naval headquarters, ALPACI, are located in Tahiti, but there is a vast distance between there and potential conflict zones in East Asia. A quick look at the map shows that Papeete is 11,587 kilometres, or 6,256 nautical miles, from Beijing. Even adding new scheduled deployments, France's two frigates, three patrol boats and five surveillance aircraft based in Noumea and Papeete have very limited firepower. This limited capacity is acknowledged by the French Defence Ministry, which notes that these French military assets are focused on humanitarian and disaster response (Ministry of Defence 2018:12).

Pacific Island governments are also seeking to broaden the dominant narrative of security in the region. Alongside traditional notions of statecentred security and transnational threats (drug smuggling, illegal fishing, organised crime), PIF members increasingly address the issue through the prism of human security, encompassing the oceans, climate change and the management of maritime resources. The 2018 PIF leaders meeting in Nauru issued the Boe Declaration, which reaffirms that 'climate change remains the single greatest threat to the livelihoods, security and wellbeing of the peoples of the Pacific and our commitment to progress the implementation of the Paris Agreement' (PIF Secretariat 2018).

However, key development partners do not prioritise funding on climate change and security, focusing instead on more traditional threats. This tension was highlighted in an interview with French Polynesian President Edouard Fritch at the 2018 PIF: 
The discussions we had this morning with our partners showed that the Indo-Pacific framework is one that everyone is using, guiding their interventions in the Pacific. Within this Indo-Pacific framework, there is certainly the problem of global warming, but there are other problems that are just as important: the security of populations, maritime security, national security for each country and also regional security. Today, Pacific countries want more security and so are looking to all their partners, whether it's China or the United States. ${ }^{4}$

This perspective of China as a development partner equivalent to the US clashes with the dominant ANZUS narrative of China as a regional security threat. Tahitian desires to increase engagement with China are in tension with Western policies of strategic denial, as France and its Anglophone partners seek to halt supposed Chinese 'debt-trap diplomacy' or the potential deployment of Beijing's military assets to assist the Chinese diaspora in the Pacific in times of conflict (Connolly 2016; Maclellan 2018b).

\section{China and the French Pacific dependencies}

The purported role of France as a bulwark against Chinese influence in the Pacific Islands is undercut by the reality that local governments and businesses in France's non-self-governing territories are actively seeking more engagement with China.

Despite this, the extent of Chinese influence in the Francophone Pacific should not be exaggerated. It's growing, but Chinese policy is marked by contradictions and setbacks.

Diplomacy in the Francophone Pacific is complicated by bureaucratic structures within China's Ministry of Foreign Affairs. China's relationship with France and its overseas dependencies is managed by the Department of European Affairs. In contrast, China's diplomacy with Australia, New Zealand, the US and the 10 China-aligned PIF countries comes under the Department of North American and Oceanian Affairs. Unlike

4 President of French Polynesia Edouard Fritch, 5 September 2018. Pacific Islands Forum, Yaren, Nauru. Interview with author. 
independent PIF countries, the French dependencies are not eligible for grants from China or programs under the new China International Development Cooperation Agency.

There is evidence of varying capability among Chinese diplomats, whooften to impress superiors at home- exhibit bullying behaviour that offends the dignity of Pacific Island leaders (Maclellan 2018c). The clumsiness of Chinese diplomacy in French Polynesia is symbolised by a long-running dispute between the Chinese consulate and local landowners in Tahiti over the ownership of the consulate building first established in Punaauia in September 2007 (Brady 2018; Radio New Zealand 2018).

A significant problem in the Francophone Pacific is China's ambivalent attitude towards decolonisation. In their long struggle for selfdetermination and independence, the Kanak people and the Maohi people are seeking international support (Maclellan 2015a). The historic support shown by the Chinese Communist Party (CCP) for the struggles of oppressed and colonised peoples has largely dissipated. Since the capitalist roaders took power in Beijing in the late 1970s, the CCP has rejected 'interference in internal affairs' that might raise parallels with Beijing's ongoing dilemmas over Tibet, Hong Kong, Taiwan and Uighur nationalism (Anonymous 2010). The Chinese Government is reluctant to criticise French colonialism, valuing France as an ally against the US in global trade and climate debates.

The Chinese Government also faces complex interactions between 'new Chinese' migrants and the long-established Chinese diaspora in the Pacific. In this regard, French Polynesia is different to the settler colonial state of New Caledonia or the smaller Wallis and Futuna. In Tahiti, Chinese migrants have long intermarried into the local elite and dominate Tahiti's business sector (Burns 2000). In New Caledonia, where a majority support ongoing ties to France, Chinese businesses often face hostility from the European, Javanese and Vietnamese communities. Chinese labourers deployed for mining construction in New Caledonia faced hostility from local unions, as they were employed outside local norms of industrial relations (Smith 2013).

Finally, analysis of China's rising influence in the Pacific Islands needs to be tempered by an understanding of the interplay between the many diverse players in the region (Maclellan 2015b; Zhang 2018a). France and the Anglosphere powers are dealing not only with China's competition 
with Taiwan, but also with new activity from a number of emerging Asian players-India, Korea and Indonesia. Major powers like France, India and Japan have their own global relationships (and tensions) with China, which complicate their interactions in the Pacific Islands region.

The following section presents four examples of the shifting relationship between China and the French Pacific dependencies: increasing exports to China from New Caledonia and French Polynesia; attempts to increase Chinese tourism by the HNA Group; the establishment of a Chinese fishing enterprise on Hao atoll in French Polynesia; and Chinese involvement in New Caledonia's nickel industry.

\section{Trade with China}

As the administering power, the French state contributes significant funding to its three Pacific dependencies, amounting to nearly $€ 2.5$ billion per annum. However-as with Australia and the independent island states-this financial support has not guaranteed that France remains their primary partner for trade.

Analysts Matthew Dornan and Sachini Muller (2018) note that Australian-Pacific Island trade is stagnating, at a time when:

trade between China and Pacific Island countries has grown rapidly, assisted by China's growing economic clout ... Since 2000, there has been a twelvefold increase in the value of Chinese exports to the region. Over the same period, imports from Australia have remained stagnant, with their value in 2017 lower than that in 2004.

This pattern can be seen with New Caledonia and French Polynesia. In 2018, China was the number one export destination for New Caledonia with 31.7 per cent of trade-due to nickel ore exportsfollowed by Korea (15.5 per cent) and Japan (14 per cent). Between 2017 and 2018, New Caledonia's trade balance with China doubled due to exports of nickel ore and ferronickel metal (ISEE 2019). Close neighbour Australia had been a primary export market for ore until the 2016 closure of the Yabulu nickel smelter in Townsville by rogue politician and entrepreneur Clive Palmer (Maclellan 2016). In 2018, Australia ranked number 11 as an export destination, receiving just 1 per cent of New Caledonian exports. 
For imports in 2018, China was the third-ranked source for New Caledonia with 9.0 per cent, after France (23.8 per cent) and Singapore (14.3 per cent). Once again, neighbouring Australia ranked lower for imports at just 7.5 per cent (ISEE 2019).

In October 2012, a Chinese business delegation visited Tahiti led by Li Xiaolin, President of the Chinese People's Association for Friendship with Foreign Countries (and the daughter of China's former prime minister Li Peng). The delegation looked at opportunities to invest in transport and tourism infrastructure as well as agriculture.

By 2018, Hong Kong and China ranked first in French Polynesia's principal export destinations (with 14.2 per cent of trade), while Australia was ranked 15th with just 0.2 per cent (ISPF 2019). In 2018, China ranked third (7.9 per cent) in the sources of imports for French Polynesia, following France (25.2 per cent) and the US (20.6 per cent). Australia again lagged at eighth position with just 2.7 per cent.

French Polynesian entrepreneurs of Chinese heritage are looking to China to expand their existing operations. Beyond agricultural products, businessman Robert Wan hopes to expand the export of cultured pearls to China beyond long-standing sales in Hong Kong. His brother Louis Wane is also seeking Chinese investment in his diverse businesses (travel, hotels, supermarkets and beverages) that already make up 12 per cent of French Polynesia's GDP (Polynésie la 1ère 2017). As detailed below, Louis Wane has already had some success in the tourism sector.

\section{Wooing Chinese tourists to the Francophone Pacific}

In 2018, Chinese travellers made nearly 150 million trips abroad (an increase of 14.7 per cent on 2017) and spent US $\$ 115$ billion during their travels (Xinhua 2019). Pacific Island countries have long worked to tap into this tourism market, seeking approved destination status from the Chinese Government. In 2004, China joined the South Pacific Tourism Organisation as the its first member state from outside the region, contributing funding previously provided by Taiwan. 
French Polynesia and New Caledonia are now following the path to increased Chinese tourism set by their independent neighbours, but the lack of direct flights from Beijing to Tahiti and Noumea has limited access to this lucrative market. Local governments are testing the waters but face significant constraints because of France's ongoing control over visas. With a policy promoting regional economic integration, the government of New Caledonia has been working to boost the number of Asia-Pacific tourists, especially from China. William Le Grand, deputy director of New Caledonia's international airline Aircalin, notes:

China is clearly a very important market with nearly 130 million tourists in 2018 around the world. That's a market to explore and we're working on it with a clear desire to investigate the possibilities there (LNC 2018b).

Despite this, the number of Chinese visitors arriving in New Caledonia will be relatively small at first. The national airline, together with hotel groups and tourist authorities, proposed a goal of just 700 tourists in 2018, another 1,000 in 2019 and rising to 6,000 by 2025 . With the establishment of a direct air route to China, tourism authorities eventually hope for 20,000 Chinese tourists a year, comprising 15 per cent of the local market (at time of writing, however, the COVID-19 (coronavirus) epidemic may complicate strategic planning for tourism industries around the Pacific).

Aircalin has begun organising charter flights from China to test the market. In February 2018, a preliminary charter with 260 Chinese tourists travelled from Hangzhou for a week-long visit to New Caledonia. In June 2018, New Caledonian authorities signed an agreement with Chinese tour operator Caissa International Travel Service, a subsidiary of Hainan Airlines (LNC 2018a). The agreement allows for three more charter flights to New Caledonia from Tianjin, a city of 15 million people located near Beijing. With two of these flights arriving in September and October 2018, the Chinese tourists were targeted with 'upmarket' services, including a visit to the outlying beaches on the Isle of Pines, a cultural 'bush visit' to the rural town of Bourail and accommodation in five-star hotels (LNC 2018d). Another 258 tourists arrived from Hangzhou in February 2019, with Aircalin's William Le Grand noting, 'With this full flight, we have the confirmation that our destination is attractive to Chinese tourists' (LNC 2019a). 
Dominique Michaud, the director general of the Marriott hotel chain in New Caledonia, noted:

We are just beginning. There is real potential but as long as there are not direct connections, the market will be limited. These facilities have been partly sorted out, as has the need to accept different types of Chinese credit cards. Chinese payments are often virtual. They pay more and more with a telephone and China is one of the most advanced countries in this manner, unlike us (LNC 2018c).

With the delivery of two new Airbus A330 aircraft during 2019, Aircalin director general Didier Tappero announced that the airline was looking to cities in China as potential regular routes, saying, 'China is an option being considered very seriously by Aircalin. Destinations like Shanghai and Hong Kong are being studied' (LNC 2019b).

Similar efforts are underway in French Polynesia. Islands like Tahiti and Bora Bora have long served as destinations for luxury tourism from the US and Europe, but tourism from Australia, New Zealand and Japan has fallen in 2017-19. According to French researcher Sebastien Goulard (2017):

Tourism has been a major economic sector for French Polynesia, comprising more than 12 per cent of its GDP. But unlike Palau and Fiji, French Polynesia has failed to become a popular destination for Chinese travellers. With less than 6,000 visitors in 2017, Chinese tourists in French Polynesia rank only eighth.

In response, French Polynesia is restructuring its tourist facilities to tap the Chinese market. Shen Zhiliang, China's consul-general in French Polynesia, agreed that Tahiti remains a luxury destination for Chinese tourists, but argued, 'You must take account of the cultural differences, the eating habits and the high cost of the trip. There is still no direct flight between China and French Polynesia' (TNTV News 2019).

Because of France's ongoing control of immigration and customs in Tahiti, Chinese tourists find it difficult to quickly organise visas for holidays there, or arrange a last-minute stopover, even though French Polynesia has held Chinese approved destination status since 2008. In an interview, French Polynesia's independence leader Oscar Temaru highlighted this ongoing colonial control of immigration as a roadblock to expanded tourism from China: 
The real problem for tourism in Tahiti is the visas. There are over a hundred countries that have to get a French visa to come and visit us, so that doesn't interest many people. You can go to lie on a beach in the sun in Fiji, in Samoa or in Vanuatu without a visa. But that's the way France wants it - they want to control everything. ${ }^{5}$

The French Polynesian Government has sought support from successive French governments in Paris for changes to French laws that could facilitate travel in larger numbers from China. They want Paris to approve short-term transit visas that could be issued to Chinese tourists on arrival at Faa'a international airport in Tahiti to increase the chance of a stopover en route to South America. The French Polynesian Government has also hoped that Paris would authorise longer-stay visas for Chinese tourists to make the long trip to Tahiti worthwhile. Currently, visa-free entry to French Polynesia for Chinese citizens can only be provided if they meet an onerous list of bureaucratic requirements (French High Commission 2019).

Gaston Flosse is a leading anti-independence politician in French Polynesia. But this long-time loyalist to the French Republic is one of the leading boosters for improved relations and economic ties with China. As president in 2004, Flosse attempted to set up a French Polynesian office in Beijing, but this attempt was overruled by the French Constitutional Court. After nine years out of office, Flosse briefly won the presidency again in 2013 and actively encouraged Chinese investment in Tahitian tourism.

Flosse led a large delegation to China in December 2013, visiting Beijing, Chungking and Haikou (the capital of the southern-most province of Hainan). During the trip, he held a series of meetings with Chinese officials, including newly elected then vice president Li Yuanchao and the chairman of the China Development Bank Hu Huaibang. Flosse held talks with Chinese civil aviation authorities and the management of Hainan Airlines to discuss the possibility of increased flights from Beijing and Haikou to Tahiti (Maclellan 2014a).

5 Former president of French Polynesia Oscar Manutahi Temaru, 30 October 2018. Ponerihouen. Interview with author. 
Over two decades, Hainan Airlines has morphed into HNA Group. The company's fortunes illustrate the challenge of boom-and-bust capitalism for Chinese companies. Between 2014 and 2017, the Chinese conglomerate took significant stakes in Hilton hotels, Swissport, Ingram Micro and Germany's Deutsche Bank. This multibillion-dollar global spending spree even extended to French Polynesia. On 28 August 2014, HNA Aviation signed a development cooperation agreement with the government of French Polynesia. This opened the way for another subsidiary of the Hainan-based corporation, HNA Tourism Company Ltd, to buy two companies belonging to prominent French Polynesian businessman Louis Wane: the SA Moorea Lagoon Resort, owner of the Hilton Moorea Lagoon Resort and Spa in Moorea, and the SARL Société Hôtelière Motu Ome'e, owner of the Hotel St Régis in Bora Bora (Tahiti Infos 2016b).

From 2017, through their subsidiary Deer Jet, HNA began offering a 'Hong Kong to Tahiti dream journey' for wealthy Chinese tourists. This trip to paradise involved a non-stop flight on a private 787 Dream Jet and a week-long stay at the presidential suite of the St Regis Bora Bora resort. Then French Polynesian tourism minister Nicole Bouteau, greeting the first flight at the airport, said, 'The Asian market, from China, is under development. It's important for us that a company like Hainan is interested in our country' (Tahiti Infos 2017).

French Polynesia has long sought Chinese investment in its ailing hotel sector, after numerous luxury resorts have closed in recent years due to high costs and a lack of Western patrons. Successive administrations have sought out Chinese investors to buy into the Mahana Beach tourism project, a planned US $\$ 2.5$ billion luxury beach resort and spa complex first proposed by Gaston Flosse.

Though he was removed from office in 2014 after convictions for corruption, Flosse opened the way for a Hong Kong-led consortium to bid for a 70-year contract to build and operate the Mahana Beach project. The consortium included the real estate firms Recas Global and R\&F Properties, together with the Chinese state-owned corporation China Railway International. In December 2015, the Chinese consortium signed a preliminary agreement with the new government of French Polynesia led by Edouard Fritch to proceed with the project. Even with the government committing to provide 53 hectares of public domain to the project, it was clear by the scheduled contract date of 30 June 2016 
that the Recas Group could not commit the financing to proceed to a full 70 -year contract, and the bid was withdrawn. Then French Polynesian tourism minister Jean-Christophe Bouissou noted:

We have avoided running aground on a hidden reef by signing a leasing contract with the Recas Group without knowing if this consortium had the capacity to develop the project or not (Tahiti Infos 2016a).

The integration of Chinese corporations into global systems of production and capital accumulation has meant they must ride the boom and bust that is a central feature of capitalist markets. The July 2018 death of HNA co-chair Wang Jian in France disrupted the company's share price. The debt crisis facing the company since 2018 has limited further expansion of global operations, including in French Polynesia. The Bora Bora property was advertised for sale in October 2018 as the HNA Group sought to sell off some of its global property holdings, reducing its stake in Hilton hotels and Deutsche Bank (Zhou 2018).

Facing collapse, the HNA Group sold nearly US\$45 billion worth of assets in 2018. However, analysts cited by the US media have raised suspicions that the company, with very deep pockets, has state backing in China (Barboza 2017; Bloomberg News 2018). In December 2019, HNA Group was granted a US\$568 million loan by Chinese stateowned banks to bail out its troubled airline subsidiaries in Hong Kong and provincial China. The bailout consortium includes the China Development Bank, China Exim Bank, Industrial and Commercial Bank of China, Bank of China Hong Kong, China Construction Bank and Agricultural Bank of China (Richter 2019).

\section{Fisheries on Hao atoll, French Polynesia}

Facing a massive trade deficit and high levels of unemployment, French Polynesia President Edouard Fritch is eager to promote investment from Chinese state-owned and private corporations in agriculture, tourism and infrastructure. In an interview, Fritch said:

China is present to support countries through investment and the technical assistance that they bring. Today, French Polynesia is certainly a country that is looking for finance and investment to support economic development. Around the Pacific, China has shown that it is making significant efforts to reduce greenhouse 
gas emissions at home, but also to provide assistance and funding to support the countries of the Pacific zone. I think that we must say that today, China is the country that is the most present in these smaller island states. ${ }^{6}$

One major investment proposal is a US\$300 million Chinese fisheries project on Hao atoll, to be operated by the Chinese corporation Tianrui Group Co. Ltd. Despite the commercial nature of the investment, Australian media have reported that the Hao project may lead to greater Chinese strategic influence. Some even suggest the project opens the way for a Chinese military facility in the French Pacific dependency. A May 2018 article in The Sydney Morning Herald stated:

The massive fish farm project on Hao atoll has raised eyebrows in Canberra because it will sit next to the airport the French military previously used to carry out nuclear tests in the Pacific ... Concerns in Canberra focused on speculation Tianrui could seek a lease on their airport, giving Beijing a strategic foothold 11,000 kilometres into the Pacific Ocean (Wroe 2018d).

The article, citing US and Australian security analysts, followed similar articles by the same journalist the previous month that raised concerns about a purported Chinese military base in Vanuatu (Wroe 2018a, 2018b, 2018c). The claims that China and non-aligned Vanuatu were planning a military facility in Luganville were quickly denied by Vanuatu Prime Minister Charlot Salwai and Foreign Minister Ralph Regenvanu (Maclellan 2018b:18). The French Government too is unlikely to welcome a Chinese military base in its Pacific dependency.

It's ironic that Western security analysts are only now expressing concern about the militarisation of Hao atoll. For decades, Hao was used by the French military as a forward base for the Centre d'Expérimentation du Pacifique (Pacific Testing Centre). Located in the Tuamotu Archipelago, Hao's 3,420-metre military airstrip is one of the longest in the Pacific. With a population of around 1,700 people, Hao served as a staging post between France, Papeete and the nuclear test sites at Moruroa and Fangataufa atolls, where France conducted 193 nuclear tests between 1966 and 1996.

6 President of French Polynesia Edouard Fritch, 5 September 2018. Pacific Islands Forum, Yaren, Nauru. Interview with author. 
Hao lagoon-one of the largest in French Polynesia-was used to decontaminate aircraft, ships and personnel exposed to radioactive contamination at the CEP. A number of studies have investigated potential nuclear contamination on the atoll (Barrillot 1996; CRIIRAD 2006). In 2006, the French Delegate for Nuclear Safety and Radiation Protection for Defence Activities revealed that large amounts of radioactive material were simply dumped in the ocean after the end of testing in 1996, including 2,656 tonnes at two sites off Moruroa atoll and 532 tonnes at Hao (DSND 2006:20-22). Worried by evidence of asbestos and other toxins on the airbase, local environmental groups have questioned whether the atoll is suitable for a fish farming project.

Given this polluted legacy, the government of French Polynesia has been trying for decades to lure investors to Hao atoll. In 2000, the Flosse Government urged foreign corporations to invest in Hao, 'a genuine tax haven in the heart of the Pacific!' Advertisements in The Economist (2000) magazine stated that Hao atoll offers 'exemption from corporate taxes, exemption from registration and property taxes, exemption from custom duties and no personal income tax'. The ad also highlighted the potential to repurpose the airstrip and facilities left behind by the French armed forces, including: 'a communication satellite network; international airport runway; wharf for deep sea ships; desalination unit; nautical base; power plant; hospital' (ibid.).

With little interest from Western corporations, the search for investors extended to China. In December 2016, Tahiti Nui Océan Foods presented a proposal for a major fisheries project on Hao. Established in 2014, Tahiti Nui Océan Foods is a subsidiary of the Tianrui Group Co. Ltd. Chaired by billionaire Li Liufa, the parent company operates from Ruzhou City, Henan Province, with investments in cement, foundry, tourism, mining, trade and logistics, finance and other industries.

In August 2017, the government of French Polynesia met with Wang Cheng, CEO of Tahiti Nui Océan Foods, and the project design was finalised on 1 February 2018. Tahiti Nui Océan Foods announced plans to build 2,800 cages in Hao's lagoon to farm fish, prawns and sea cucumbers for export. To woo the investors, the Fritch Government passed legislation in December 2017 allowing for fiscal incentives that encourage major investments in French Polynesia, followed by a decree on 8 March 2018 to create a priority development zone on Hao atoll (Government of French Polynesia 2017, 2018a). 
Early publicity in 2016 stated that up to 10,000 jobs would be created, but the scale and cost of the project have been downsized several times and the start of construction regularly delayed. Early company propaganda suggested would make a US $\$ 1.5$ billion investment and, years later, security analysts and journalists continue to recycle this figure without investigation (see, for example, Wroe 2018d). This comes despite a publicly available French Polynesian Government decree that shows Tahiti Nui Océan Foods will only invest CFP32 billion (French Pacific francs), equivalent to US $\$ 300$ million (Government of French Polynesia 2018b:6192).

Desperate to generate employment on the atoll, the French Polynesian Government has wooed Tahiti Nui Océan Foods CEO Wang Cheng, even presenting him with the honorific of Commandeur dans l'ordre de Tahiti nui in May 2018. But the delay in construction and the likelihood that local jobs will be numbered in the hundreds, not thousands, is causing political problems for local boosters of the project. Seeking reelection in March 2020, Hao Mayor Théodore Tuahine complained that his constituents were originally promised 10,000 jobs. He was also concerned that the island cannot train local workers for the project without knowing the types of positions that will be available for Polynesians rather than Chinese staff:

There is a lack of detailed information on the project. They talk about the need for workers and their preparation, which we're ready to do. But we don't know what are the technical specialities that they want us to prepare! (Tahiti Infos 2019).

The Hao project highlights the reality that initiatives in the Pacific are often driven by the commercial interests of private or state-owned corporations, rather than overarching government plans. Chinese diplomats are often reliant on the Chinese company for information about progress or the contents of deals struck with the host government. In an interview in early 2019, China's consul-general in French Polynesia Shen Zhiliang reaffirmed his belief that the Hao project will eventually begin:

In May 2018, there was an inauguration ceremony on Hao and in August a delegation from the China Development Bank came to inspect the works and for deeper discussions. The two parties are both in contact. Polynesian engineers will soon be sent to Shanghai [for training]. I think the project is still on track. Neither of the two parties has indicated to me an intention to abandon the project (TNTV News 2019). 
This project is often presented in the Western media as an example of Chinese debt-trap diplomacy, but any debt will rest with the Chinese corporation. Indeed, the agreement signed by the Fritch Government on 29 March 2018 shows that the government has agreed to exempt Tahiti Nui Océan Foods from any tax for 30 years on the importation of materials and fuel. It has also agreed to several other tax holidays for a period of 10 years after construction has been completed (Government of French Polynesia 2018b). In mid-2019, the Fritch Government granted the Chinese corporation a further year to build a 1.2 million litre fuel tank for the project.

On the basis of public documents, neither the Chinese company nor the Chinese state retains control over the airstrip on Hao atoll. With the French Government in Paris signing off on the project, eager to reduce its own state revenues flowing into French Polynesia, there is little evidence that the project gives 'Beijing a strategic foothold 11,000 kilometres into the Pacific Ocean' (Wroe 2018d).

In the future, however, other Chinese corporations may express interest in the vast maritime zone around Clipperton and French Polynesia's five archipelagos. In June 2017, under China's vision of a 21st-century Maritime Silk Road, Beijing proposed three 'blue economic passages' (including a China-Oceania-South Pacific passage) to focus on 'sharing blue space and developing the blue economy' (Xinhua 2017). The University of French Polynesia hosted a seminar on the Maritime Silk Road in November 2019.

There is also growing interest in deep-sea mining from the China Ocean Mineral Resources Research and Development Association (Zhang 2018b). The sector, however, is still governed by the French State- under French Polynesia's current autonomy statute, control of 'strategic metals' on the ocean floor rests with Paris rather than Papeete (Blue Ocean Law et al. 2019; Maclellan 2018d). France is firmly focused on controlling the vast $7,000,000 \mathrm{~km}^{2}$ exclusive economic zones (EEZs) surrounding its Pacific colonies, as a French Senate report has highlighted:

Thanks to its overseas possessions, France is one of the countries affected - indeed the most affected - by this revolution in sharing the oceans. Its EEZ is in fact the second largest behind that of the United States and beyond this, the most diverse. Present in both hemispheres and at all points of the compass, the French EEZ is the only one on which the sun never sets (Senate 2014:13). 
Questioned about potential Chinese interest in fisheries during a February 2016 visit to Tahiti, then French president Francois Hollande stressed the importance of ongoing French state sovereignty over French Polynesia's $5,000,000 \mathrm{~km}^{2}$ EEZ (Hollande 2016). However, France's sovereignty over EEZs pits the French state against the leading independence party in French Polynesia, which is actively asserting local rights over marine resources under international law. Former senator for French Polynesia Richard Ariihau Tuheiava has argued:

We have continually emphasised the critical nature of the resource question as a core issue for our future development. Whether or not these resources are considered in Paris to be 'strategic' is irrelevant to the applicability of international legal decisions which place the ownership of natural resources with the people of the non-self-governing territories (Tuheiava 2017).

\section{Exporting nickel from New Caledonia}

At current estimates, the Melanesian nation of New Caledonia holds more than 25 per cent of global nickel reserves. The main island Grande Terre is bisected by a massive mountain range filled with vast ore bodies. New Caledonia is often called Le Caillou, an ironic reference to the French word for pebble.

Conservative anti-independence politicians have argued that China's global efforts to access natural resources pose a particular challenge for New Caledonia due to its strategic mineral reserves. Philippe Gomès, leader of Calédonie Ensemble, a major conservative party in New Caledonia and a strong opponent of independence, argued that China is more interested in New Caledonia than other member countries of the Melanesian Spearhead Group (though this may come as a surprise to Papua New Guineans and Fijians). In an interview, the anti-independence leader said:

On the need for raw materials, who has the greatest demand for nickel on a global scale? The Chinese! We have the second largest reserves of nickel in the world. If they colonise Solomon Islands, Fiji or Papua New Guinea, they'll get beaches and coconut palms. But New Caledonia is le Caillou - the largest rock of nickel in the world. So, they're eyeing us with a hundred, a thousand, times more interest that any atoll in the world with their coconut trees. ${ }^{7}$

7 Philippe Gomès, President of Calédonie Ensemble and deputy to the French National Assembly, 17 October 2018. Noumea. Interview with author. 
In contrast, members of the independence movement Front de Libération Nationale Kanak et Socialiste (FLNKS) have been eager to break the French monopoly over the smelting of nickel in New Caledonia. They have looked beyond traditional markets in France, Japan and Australia to new partners in China and South Korea to add value to New Caledonia's vast natural resources.

New Caledonia's Northern Province administration is controlled by the FLNKS independence movement under provincial President Paul Neaoutyine. Following the armed conflict of the 1980s, the provincial administration established a development arm, Société de Financement et d'Investissement de la Province Nord (SOFINOR), to expand economic opportunities in the rural north, where the population is majority indigenous Kanak. In 1990, SOFINOR bought the mining company Société Minière du Sud Pacifique (SMSP).

Following the 1969 Billotte laws, a monopoly over nickel smelting was guaranteed to the French-controlled corporation ERAMET and its local subsidiary Société le Nickel (SLN), which operates the Doniambo smelter in Noumea. The French Government has used its Strategic Investment Fund to maintain a 25 per cent holding in ERAMET. French taxpayer funds have often been used to bail out SLN as nickel prices fluctuate on the international market.

After New Caledonia's violent conflict of the 1980s, Kanak independence leaders sought to open the nickel sector to foreign competition. The signing of the Noumea Accord in May 1998 was only possible because contending parties had come to an agreement over the préalable minière (mining precondition) posed by the independence movement. The February 1998 Bercy Accord allowed the transfer of strategic deposits of high-grade nickel ore to SMSP and SOFINOR, opening the way for the construction of the Koniambo nickel smelter in the north of the country.

In his role as a New Caledonian Deputy in the French National Assembly, Philippe Gomès accompanied President Macron to Australia in May 2018. During the trip, Gomès said that New Caledonia 'could fall into Chinese hands' if people voted for independence in the territory's November 2018 referendum on self-determination (Higgins 2018). Ironically, at that time it was the government of New Caledonia, led by a member of Gomès' own party, that played a crucial role in opening the way for greater Chinese involvement in New Caledonia's nickel industry. 
Government policy since 2009 has tried to add value to the country's vast nickel reserves by expanding the amount of smelted metal rather than exporting raw saprolite or laterite ores. Despite this, ore exports grew by 24 per cent between 2013 and 2015, with the growth focused on China, Japan and Korea. Though New Caledonia has long looked to Japan and Australia for exports, for many years it resisted sales of high-grade ore directly to China in hopes of protecting metal production in local smelting plants.

In March 2016, Queensland Nickel's Yabulu smelter, owned by flamboyant entrepreneur and novice politician Clive Palmer, went into liquidation, even as ships bearing ore were on the water between New Caledonia and Australia (Maclellan 2016). Small mining companies, known as petits mineurs, lost their export market. Faced with the threat of strikes and blockades by subcontractors, the New Caledonian Government buckled. In a new plan, then president Philippe Germain announced that his government would grant temporary permits for the export of nickel ore to China. In an interview, Germain said:

Our mining framework has always prioritised traditional partners like Australia and Japan. But if Australia can no longer buy the same levels from us, we need an alternative in the current circumstances, because we have mines, miners and sub-contractors who are dependent on this activity. ${ }^{8}$

In 2018, New Caledonia exported 6.8 million tonnes of ore, including 3.3 million tonnes to South Korea, nearly 2 million to Japan and 1.5 million to China. However, this tonnage to China is only half the 3 million tonnes authorised for export each year. A number of mining companies are now eager to expand into this market. Thibaut Martelin, president of the minerals export council Syndicat des Exportateurs de Minerai, has stressed the long-term importance of China over traditional export destinations like Japan and Australia:

China effectively serves as a complete substitute for Australia ... The current Chinese market is a huge advantage in comparison to the Australian market because it is open to export from a number of smelters and with a greater range of minerals (content of nickel, amount of nickel in ferronickel, etc). Today, we face less constraints

8 Then president of New Caledonia Philippe Germain, 8 March 2016. Noumea. Interview with author. 
within the Chinese market. There's a larger pool of clients who will adapt their operations to the ore that's available, rather than the mine having to adapt its operations to the customer (LNC 2019c).

The biggest beneficiary of the opening of export to China has been the Northern Province's SMSP, which has expanded access to the Chinese market as part of a broader development strategy.

Over the last three decades, SMSP has grown into a major nickel producer. The driving force behind the company is New Caledonian entrepreneur Dang Van Nha, known as Andre Dang. His parents arrived in New Caledonia from French Indochina in 1935, working as indentured labourers in the Koniambo Massif mines owned by SLN. His father died in an industrial accident when Dang was just 17 months old, and the family moved to Noumea, where Dang became an accountant, manager and then leading businessman (Maclellan 2014b).

During New Caledonia's armed conflict of the 1980s, Dang was driven into exile in Australia, with the colonial right perceiving him as too close to the FLNKS independence movement. However, he returned to New Caledonia in 1990 to assist the Northern Province in managing its mining and smelting operations.

Begun in 1990 as a mining transport company with 120 employees, SMSP started exporting nickel ore in 2007. SMSP's strategy has been to retain high-value saprolite ore from the Koniambo Massif for domestic use. This ore, with 2.3 per cent nickel content, is being supplied to a new smelter established in the Northern Province: the US\$5.3 billion plant at Vavouto operated by Koniambo Nickel SAS (KNS), a joint venture between SMSP and the transnational conglomerate Glencore. In an unprecedented arrangement, Dang persuaded the Anglo-Swiss financial conglomerate to grant SMSP 51 per cent controlling interest in KNS.

This chapter cannot detail the full range of social, environmental and economic impacts of the Koniambo project, but it has been a fundamentally transformative project in the Northern Province and a crucial pillar of the 'economic rebalancing' required under the 1998 Noumea Accord (Grochain 2013; Sourisseau et al. 2017).

To generate funding for its share of Koniambo finances, SMSP developed a strategy to export lower-grade nickel ore to Korea and China, once again using joint ventures controlled 51 per cent by SMSP. The company has two joint ventures with the Korean corporation Posco: the Nickel Mining 
Company (NMC) and the nickel processing company Société du Nickel de Nouvelle-Calédonie et Corée (SNNC). In 2009, SNNC began smelting nickel at the company's plant at Gwangyang, South Korea, producing 261,469 tonnes of nickel metal between 2009 and 2017. In the same period, SMSP's subsidiary NMC exported nearly 20,000,000 tonnes of ore to the Gwangyang plant, which uses lower-grade saprolite ore with an average of 1.98 per cent nickel content.

The next challenge was to export even lower-grade ore, with an average nickel content of 1.65 per cent, to a joint-venture smelter in China. On 18 October 2017, SMSP signed a memorandum of understanding (MOU) with Yangzhou Yichuan Nickel Industry Co. Ltd to develop a joint project in China. This MOU was expanded on 22 March 2018 when Andre Dang met Yichuan CEO Zhang Jianguo to finalise a memorandum of agreement (MOA).

These preliminary agreements were designed to test export systems to China before finalisation of a full contract, under which SMSP agrees to deliver 600,000 tonnes of nickel ore to Yichuan each year for the next 25 years, after the Chinese corporation agrees to sell 51 per cent of its share capital to SMSP. The full contract was finalised in 2020, though exports were slow to expand due to the coronavirus pandemic.

In an interview, SOFINOR's chief financial officer Karl Therby explained that Yichuan's pyro-metallurgical smelter at Yangzhou began production in 2012:

The Chinese had been purchasing nickel ore from Indonesia, but they had a range of concerns about the quality, the humidity of the ore and of the reliability of delivery. So SMSP was able to say to them that, through our Korean operation, we have shown our capacity and reliability to export ore of higher quality than can be found in the Indonesian market. So, by signing the contract with us, they've guaranteed supply—but we retain 51 per cent of the operation. ${ }^{9}$

The decision to operate offshore was driven by domestic politics as well as market realities. Conservative anti-independence parties in Noumea are fiercely opposed to Chinese investment in New Caledonian enterprises,

9 Karl Therby, chief financial officer of Société de Financement et d'Investissement de la Province Nord (SOFINOR), 7 November 2018. Noumea. Interview with author. 
so SOFINOR and SMSP have developed new ways of working without Chinese companies operating in New Caledonia. SOFINOR's Therby explained:

In our political context, with referendums on independence and public concern about Chinese influence, we don't want them to operate here. We've seen what has happened in Papua New Guinea, we've seen what has happened in Vanuatu and we want to protect the territory from all that. So, they have no actual investment in our mines; instead, we just have a contract to supply them. ${ }^{10}$

In an interview, Andre Dang explained that this strategy is based on an unprecedented corporate structure that gives majority control to SMSP rather than its Chinese partner:

The corporate structure is a real innovation and it's the first time in the world that it's been used, above all in China. The structure of 51 per cent $/ 49$ per cent-the Chinese have never before accepted this. The Chinese Government was obliged to change a law and it took seven years to allow SMSP to start operations there. We've just taken one small step into the Chinese market. After that we'll see, because the Chinese are very intelligent. We have to be very careful, because they can be terrible! The Chinese aren't here, they've stayed at home! Instead, we've gone over there and have taken possession of a small piece of their country, through our 51 per cent control of the smelter. The cost of operations will be paid for by the profits from the smelting. ${ }^{11}$

In 2018, after striking an agreement with SMSP, Yangzhou Yichuan Nickel added a second production line to its Yangzhou smelter, increasing potential annual production capacity of ferronickel. The metal is then sold to stainless steel producers in China. In July 2018, Northern Province President Paul Neaoutyine paid an official visit to China to meet with officials from Yangzhou City and major shareholders from Yangzhou Yichuan Nickel (SMSP 2018).

The first shipment to China under the MOA, departing Noumea in July 2018, revealed some early tensions with the Chinese corporate partner. The Yangzhou port, in a shallow river channel, only has capacity for vessels weighing 45,000 tonnes, but the first shipment of ore from

10 Karl Therby, chief financial officer of Société de Financement et d'Investissement de la Province Nord (SOFINOR), 7 November 2018. Noumea. Interview with author.

11 Andre Dang Van Nha, 7 November 2018. Noumea. Interview with author. 
New Caledonia amounted to 62,500 tonnes. Without informing SMSP or the New Caledonian mining directorate, Yinchuan unloaded 16,006 tonnes at Lianyungang port rather than deliver the full load to the Yangzhou smelter.

To assert SMSP's rights as controlling partner, Dang halted further shipments until the Chinese company apologised and agreed to bear the costs of transhipment to smaller vessels. This ensured all the ore was used at the Yangzhou smelter, thereby generating maximum returns to SMSP as controlling partner. New shipments recommenced in January 2019, with ore loading through the Bay of Téoudié at Kaala-Gomen. By May 2019, there had been three shipments, with plans to ramp up to a vessel every month.

For Dang, this strategy of maintaining majority control over operations avoids many of the problems that independent Pacific countries have faced with Chinese mining investments. He contrasts the SMSP strategy with the US\$1.4 billion Ramu Nickel project in Papua New Guinea, which has been plagued by the overuse of Chinese labour, poor environmental standards and pressure on local politicians (Smith 2013). Now in his 80s, Dang will be a hard man to replace as a negotiator of unprecedented deals with China. He is, however, grooming successors to implement the vision already laid out:

As long as I'm at the company, I will never allow it to sell nickel ore directly to China. I only want our resource to be used in New Caledonian plants or those that will be owned by New Caledonia in the future and that will supply benefits to our country. We're going to shoot ourselves in the foot if we simply provide raw minerals to our competitors. That's been going on for 140 years, ever since colonisation.

We want to ensure the continued existence of our mines, because nickel is not a renewable resource. Once you've exhausted it, bit by bit, that's the end. We don't want New Caledonia to end up like Nauru. They were a world leader in phosphate mining, but they abused it and used it all up. They are a sad country. So, our strategy is to add value to the resource which can generate funds for use in sectors beyond the nickel industry, which will benefit the country and future generations. ${ }^{12}$

12 Andre Dang Van Nha, 7 November 2018. Noumea. Interview with author. 


\section{Conclusion}

As a key member of the European Union (EU), France is well positioned for a new post-Brexit relationship with the Pacific Islands. But, at this time of geopolitical change, governments in Noumea and Papeete are eagerly seeking Chinese grants and investment in tourism, fisheries and infrastructure, as well as export markets for New Caledonia's nickel industry and French Polynesian pearls. As yet, there are only a small number of direct investments by Chinese corporations, but trade relations are shifting rapidly from Europe to Asia, for the French dependencies as well as independent PIF countries.

These changes come at a time when PIF member states have begun to reposition themselves with other European powers. For many years, France and the United Kingdom have contributed significant development assistance to the Pacific through the EU's European Development Fund (EDF). However, the future of EDF funding is in flux in the aftermath of the June 2016 Brexit referendum, Boris Johnson's December 2019 electoral victory and the looming renegotiation of the 2000 Cotonou Treaty between the EU and the Organisation of African, Caribbean and Pacific nations.

The election of Emmanuel Macron as President in 2017 highlighted the crisis facing France's traditional centre-right and centre-left parties. But Macron's République En Marche movement is facing its own crisis, with popular rioting around the country in 2018-19 by the gilets jaunes (yellow vests) and massive public service strikes in late 2019.

France's strategic role in the Pacific has support within the French state, given the costs and benefits of empire are unevenly shared. Most metropolitan citizens have limited awareness of the overseas collectivities, so institutions that benefit from the maintenance of colonialism play a disproportionate role in policy formulation. Most politicians and officials in Paris still believe that the costs of maintaining a colonial empire are ones that must be borne, with a report from the French Senate noting:

The exercise of our sovereignty over these vast stretches and the international competition we face are certainly a difficult cost to bear in this period of crisis. But this is an investment for the future, an historic opportunity for growth and expansion. France, with its overseas territories on the front rank, must seize this opportunity and bet on the blue economy (Senate 2014:13). 
Will this gamble pay off, or will France be unable to finance its multibillion-euro commitment in the South Pacific well into the 21 st century? And will China be willing to step up to plug the development gap?

\section{References}

Anonymous 2010. China and the Principle of Self-Determination of Peoples. St Antony's International Review 6(1):79-102.

Barboza, D. 2017. A Chinese Giant Is on a Global Buying Spree. Who's Behind It? New York Times, 9 May.

Barrillot, B. 1996. Contamination et État de Pollution à Hao. In B. Barrillot. Les Essais Nucléaires Français 1960-1996. Lyon: CDRPC, 263-70.

Bloomberg News 2018. HNA Is Victim of Conspiracy Against China: Co-Chairman. 7 February.

Blue Ocean Law, the Pacific Network on Globalisation and the International Justice and Human Rights Clinic at Allard Law School, University of British Columbia 2019. Enduring Colonization-How France's Ongoing Control of French Polynesia Resources Violates the International Law of Self-Determination. Guahan: Blue Ocean Law.

Brady, A-M. 2018. Trouble in Paradise: A Chinese Occupation in Tahiti. The Diplomat, 20 April.

Brattberg, E., P. Le Corre and E. Soula 2018. Can France and the UK Pivot to the Pacific? Carnegie Endowment for International Peace, 5 July.

Burns, M. 2000. The Chinese Community in French Polynesia: Scholarly Sources of Understanding. China Review International 7(1):28-35. doi.org/10.1353/ cri. 2000.0008

Carroll, J. and T. Ell 2017. More Than Submarines: New Dimensions in the Australia-France Strategic Partnership. Strategy Paper, Australian Strategic Policy Institute, Canberra.

Connolly, P. 2016. Engaging China's New Foreign Policy in the South Pacific. Australian Journal of International Affairs 70:5:484-505. doi.org/10.1080/ 10357718.2016.1194805

CRIIRAD (Commission de Recherche et d'Information Indépendantes sur la Radioactivité) 2006. Compte Rendu de la Mission Préliminaire de Contrôles Radiologiques sur l'Ile de Mangareva et les Atolls de Tureai et Hao (Polynésie Française). CRIIRAD Rapport $N^{\circ}$ 05-49 V3. 
DFAT (Department of Foreign Affairs and Trade) 2017. 2017 Foreign Policy White Paper: Opportunity Security Strength. Canberra: Government of Australia.

Dornan, M. and S. Muller 2018. The China Shift in Pacific Trade. Devpolicy Blog, 15 November.

DSND (Délégué à la Sûreté Nucléaire et à la Radioprotection pour les Activités Intéressant la Défense) 2006. Les Essais Nucléaires Français dans le Pacifique: Mission du délègue à la Sureté Nucléaire et à la Radioprotection pour les activités et Installations Intéressant la Défense. Paris: Ministère de la Défense.

Fisher, D. 2015. One Among Many: Changing Geostrategic Interests and Challenges for France in the South Pacific. Les Etudes du CERI 216.

French High Commission 2019. Dispense de Visa pour les Ressortissants de Certains Pays pour Entrer et Séjourner en Polynésie Française, pour Une Durée Inférieure à 15 Jours. Regulations issued by French High Commission in French Polynesia, Papeete, 22 October.

Fritch, E. 2019. Route de la Soie/Axe Indo-Pacifique. Speech at the University of French Polynesia, Tahiti, 5 November.

Goulard, S. 2017. French Polynesia at the Chinese Crossroads. The Diplomat, 7 September.

Government of French Polynesia 2017. Loi du Pays N²017-43 du 22 Décembre 2017 Portant Incitations Fiscales à la Réalisation de Grands Investissements en Polynésie Française. Conseil des Ministres.

Government of French Polynesia 2018a. Arrêté No 315 CM du 8 Mars 2018 Portant Création de la Zone de Développement Prioritaire de Hao, Situé sur le Territoire de la Commune de Hao, dans l'Archipel des Tuamotu. Conseil des Ministres.

Government of French Polynesia 2018b. Arrêté N 500 CM du 29 Mars 2018 Portant Agrément de la Société Tahiti Nui Océan Foods et de Son Projet d'Implantation et d'Exploitation d'une Ferme Aquacole sur l'Atoll de Hao, au Dispositif de la Loi de Pays N²017-43 du 22 Décembre 2017 Portant Incitations Fiscales à la Réalisation de Grands Investissements en Polynésie française. Conseil de Ministres. Journal Officiel de la Polynésie Française 6192-93.

Grochain, S. 2013. Les Dynamiques Sociétales du Projet Koniambo. Noumea: Editions IAC.

Hacquemand, E. 2018. En Nouvelle-Calédonie, la Méthode Macron à l'œuvre. Paris Match, 10 May. 
Higgins, E. 2018. New Caledonia 'Could Fall into Chinese Hands' If It Votes for Independence. The Australian, 4 May.

Hollande, F. 2016. Press conference, Tahiti, French Polynesia, 22 February.

ISEE (Institut de la Statistique et des Études Économiques) 2019. Commerce Extérieure 2018. Noumea: Institut de la Statistique et des Études Économiques.

ISPF (Institut de Statistiques de la Polynésie Française) 2019. Le Commerce Extérieur en Polynésie Française. Papeete: Institut de Statistiques de la Polynésie française.

L'Express 2018. Emmanuel Macron Souhaite un 'Nouvel axe Indo-Pacifique' avec l'Australie. 2 May.

LNC (Les Nouvelles Calédoniennes) 2018a. Aircalin Signe pour Trois Nouveaux Vols Charters en Provenance de Chine, 1 June.

LNC (Les Nouvelles Calédoniennes) 2018b. Le Tourisme Local Rapporte Plus de 5 Milliards, 4 June.

LNC (Les Nouvelles Calédoniennes) 2018c. Pour Tout Projet, Rien Ne Se Fait sans une Adhésion Fortement Majoritaire, 1 October.

LNC (Les Nouvelles Calédoniennes) 2018d. Un Deuxième Charter Chinois Accueilli à La Tontouta, 28 September.

LNC (Les Nouvelles Calédoniennes) 2019a. Arrivée d'un Troisième Charter de 258 Touristes Chinois, 5 February.

LNC (Les Nouvelles Calédoniennes) 2019b. Bienvenue à Bord du Nouvel Avion d'Aircalin, l'A330neo Kanuméra, 2 August.

LNC (Les Nouvelles Calédoniennes) 2019c. Le Marché Chinois a Cet Immense Avantage d'Être Ouvert sur Plusieurs Usines, 17 April.

Maclellan, N. 2009. The Australia-France Defence Co-Operation Agreement: Implications for France in the South Pacific. Austral Policy Forum 09-19A. Nautilus Institute.

Maclellan, N. 2012. Partenariat Stratégique Renforcé entre la France et l'Australie. Tahiti-Pacifique Magazine 254 (August).

Maclellan, N. 2014a. Flosse Taps Beijing-Tahiti Connection for Increased Tourism. Islands Business, 13 February.

Maclellan, N. 2014b. Mr. Nickel—SMSP's Andre Dang Transforms New Caledonia's Nickel Industry. Islands Business, 20 June. 
Maclellan, N. 2015a. Pacific Diplomacy and Decolonisation in the 21st Century. In G. Fry and S. Tarte (eds), The New Pacific Diplomacy. Canberra: ANU Press. doi.org/10.22459/NPD.12.2015.21

Maclellan, N. 2015b. Transforming the Regional Architecture: New Players and Challenges for the Pacific Islands. Asia-Pacific Issues 118. Honolulu: East-West Center.

Maclellan, N. 2016. Palmer's Folly and the Road to New Caledonian Independence. Inside Story, 26 May.

Maclellan, N. 2018a. Operation South Pacific? Inside Story, 29 March.

Maclellan, N. 2018b. Vanuatu Dismisses China Base Claim. Islands Business, May.

Maclellan, N. 2018c. Chinese Walkout. Pacnews, 4 September.

Maclellan, N. 2018d. France and the Blue Pacific. Asia and the Pacific Policy Studies September 5(3):426-41. doi.org/10.1002/app5.228

Maclellan, N. 2020. Global Britain's Frayed Edges. Inside Story, 7 February.

Macron, E. 2018. Speech, Noumea, New Caledonia, 5 May.

Malielegaoi, L.S.M. 2018. Speech at 73rd Session of the United Nations General Assembly, New York, 28 September.

Marles, R. 2012. Interview with then ALP Parliamentary Secretary for Pacific Island Affairs Richard Marles on Pacific Beat program. ABC News, 10 September. Radio Australia.

Ministry of Defence 2018. France and Security in the Indo-Pacific. Paris: Ministry of Defence.

Nicholson, B. 2016. French Call for Defence Ties across Oceans. The Australian, 2 March.

Panda, A. 2016. French Defence Minister to Urge EU South China Sea Patrols. The Diplomat, 6 June.

Patrick, A. 2018. Emmanuel Macron is More Worried about New Caledonia than Australia. Australian Financial Review, 2 May.

PIF (Pacific Islands Forum) Secretariat 2016. Final Communiqué. Forty-Seventh Pacific Islands Forum. Pohnpei, Federated States of Micronesia, 8-10 September.

PIF (Pacific Islands Forum) Secretariat 2018. Boe Declaration. Attachment to Final Communiqué. Forty-Ninth Pacific Islands Forum. Boe, Nauru, 5 September. 
Polynésie la 1ère 2017. Combien Pèse le Groupe Wane en Polynésie? 12 August.

Radio New Zealand 2018. Chinese Consulate Renews Tahiti Rental Amid Controversy. 26 April.

Richter, W. 2019. HNA Gets Chopped Up, Its Many Airlines Buckle and Get Bailouts to Dodge Messy Collapse, But Its Hong Kong Airlines? Wolf Street, 3 December.

Rigaud, N. 2016. France and Security in the Asia-Pacific. ASPI Strategic Insights 112. Canberra: Australian Strategic Policy Institute.

Senate 2014. Rapport d'Information Fait au Nom de la Délégation Sénatoriale à l'Outre-Mer, sur Zones Économiques Exclusives des Outre-mer: Quels Enjeux? Senat $N^{\circ} 430$ (2013-14).

Smith, G. 2013. Spare a Nickel? On the Trail of Chinese Resource Investment in the Pacific. The China Story. The Australian Centre on China in the World, College of Asia \& the Pacific, The Australian National University.

SMSP (Société Minière du Sud Pacifique) 2018. President Paul Néaoutyine Visits China, 30 July.

Sourisseau, J-M., S. Grochain and D. Poithily 2017. From Anticipation to Practice: Social and Economic Management of a Nickel Plant's Establishment in New Caledonia's North Province. In C. Filer and P.-Y. Le Meur (eds), LargeScale Mines and Local-Level Politics: Between New Caledonia and Papua New Guinea. Canberra: ANU Press, 61-98. doi.org/10.22459/LMLP.10.2017.02

Tahiti Infos 2016a. De Nouveaux Investisseurs Intéressés par le Projet Tahiti Mahana Beach, 5 July.

Tahiti Infos 2016b. Le Chinois Hainan Airlines Group Rachète deux Hôtels du Groupe Wane, 20 April.

Tahiti Infos 2017. Hainan Airlines à la Conquête du Ciel Polynésien, 20 October.

Tahiti Infos 2019. Projet Aquacole de Hao : Près de 240 Containers Attendus en Avril, 16 January.

Tavola, K. 2019. 'Enduring Colonialism' Raises Vexatious Questions for Pacific Islands Forum. Islands Business, 30 August.

The Economist 2000. Government of French Polynesia Advertisement. April.

TNTV News 2019. Bateaux de Pêche, Hao, Tourisme: Entretien avec le Consul de Chine en Polynésie, 30 March. 
Tuheiava, R. 2017. Speech to the Pacific Regional Seminar of the UN Special Committee on Decolonisation, Nicaragua, 24 June.

Turnbull, M. and E. Macron 2018. Press conference with Prime Minister of Australia Malcolm Turnbull and President of the French Republic Emmanuel Macron, Kirribilli House, Sydney, Australia, 2 May.

Vandendyck, B. 2018. Le Développement de l'Influence Chinoise dans le Pacifique Océanien. Revue Juridique, Politique et Économique de la NouvelleCalédonie 2018/1(31):199-209.

Wroe, D. 2018a. China Eyes Vanuatu Military Base in Plan with Global Ramifications. The Sydney Morning Herald, 9 April.

Wroe, D. 2018b. Chinese Wharf in Vanuatu Raising Eyebrows across the Pacific. The Sydney Morning Herald, 12 April.

Wroe, D. 2018c. Vanuatu PM Defends China Deals But Vows to Oppose Any New Foreign Base. The Sydney Morning Herald, 12 April.

Wroe, D. 2018d. China Casts Its Net Deep into the Pacific with \$2b Fish Farm. The Sydney Morning Herald, 18 May.

Xinhua 2017. China Proposes 'Blue Economic Passages' for Maritime, 21 June.

Xinhua 2019. Chinese Tourists Make Nearly 150 Million Outbound Trips in 2018, 14 February.

Zhang, D. 2018a. China, India and Japan in the Pacific: Latest Developments, Motivations and Impact. DPA Discussion Paper 2018/6. Canberra: The Australian National University.

Zhang, D. 2018b. China's Growing Interest in Deep Sea Mining in the Pacific. DPA In Brief 2018/11. Canberra: The Australian National University.

Zhou, E. 2018. HNA Adds Nine Overseas Properties to Fire Sale. Mingtiandi, 14 October. 
This text is taken from The China Alternative: Changing Regional Order in the Pacific Islands, edited by Graeme Smith and Terence Wesley-Smith, published 2021 by ANU Press, The Australian National University, Canberra, Australia.

doi.org/10.22459/CA.2021.06 